100-osioms gimimo metinėms

\title{
A. VOKIETAITIS - VIENAS LIETUVOS KŪNO KULTŪROS, SPORTO SISTEMOS KŪRĖJŲ: TEORINĖS IZZZVALGOS IR PRAKTIKA
}

Stanislovas Stonkus

Lietuvos kūno kultūros akademija, Kaunas, Lietuva

Stanislovas Stonkus. Habilituotas socialinių mokslų daktaras. Lietuvos kūno kultūros akademijos Sportinių žaidimų katedros profesorius. Mokslinių tyrimų kryptys: kūno kultūros, sporto istorija ir terminologija; krepšinio komandų ir žaidèjų rengimo, žaidimo problemos.

\section{SANTRAUKA}

Didejjant dèmesiui kūno kultūrai, sportui, vis daugiau žmoniu mégina išsiaiškinti savo požiūrị, santykỉ su kūno kultūra, fiziniu lavinimu, sportu, ju moralinius ugdomuosius ir taikomuosius veiksnius, rasti savo vieta tuose vyksmuose.

Straipsnyje aptarti XX a. ketvirtame dešimtmetyje pateikti A. Vo-

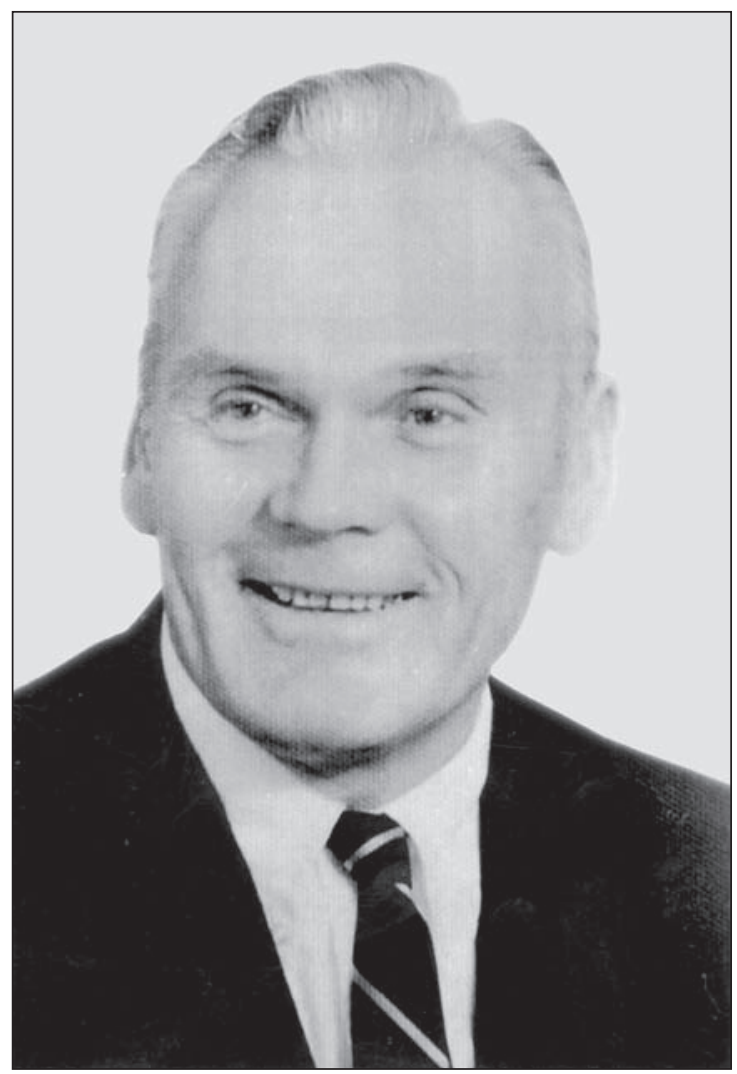
kietaičio pamatiniai teoriniai teiginiai, ju pritaikymas, turèje didelès itakos formuojant Lietuvos fizinio auklejjimo, sporto sistemq. Jie neprarado savo teorinès bei praktinès vertès ir dabar.

A. Vokietaitis natūraliaja gimnastikq laikè svarbiu žmogaus kūno lavinimo veiksniu. Žmogaus fizinio auklëjimo vyksme jis akcentuoja gimnastika, žaidimus, plaukima.

A. Vokietaitis, aptardamas pagrindines squvokas, išskiria fizinį lavinima, fizinį auklëjimq, kūno kultūra, sportq. Kalbèdamas apie kūno kultūra, pabrëžia kūno kultūros ir bendrosios kultūros sqasaja. Sporta jis suvoke kaip tam tikra kūno lavinimo forma, pasigesdamas bendrosios kultūros siekimo.

Teorines prielaidas A. Vokietaitis diegè i praktikq rengdamas mokyklinę fizinio auklèjimo sistema, kūno kultūros programa kaimo jaunimui.

Raktažodžiai: natūralus judesys, natūralioji gimnastika, kūno lavinimas, fizinis auklëjimas, kūno kultūra, sportas.

Turiningas, bet sudėtingas gyvenimo kelias. Algirdas Vokietaitis gimè $1909 \mathrm{~m}$. kovo $9 \mathrm{~d}$. Kaune, žymaus Lietuvos pedagogo Juozo Vokietaičio ir Magdalenos Tekoriūtės šeimoje. 1926 m. baigęs Kauno „Aušros“ gimnazija, 1926-1930 m. Kauno universitete studijavo iš pradžių agronomiją, vèliau istoriją ir pedagogiką. 1927 m. baigè vasaros kursus kūno kultūros mokytojams, o 1929 m. tèvo paragintas išlaikė egzaminus ir igijo kūno kultūros mokytojo teises. A. Vokietaitis: Kürybingiausias mano gyvenimo periodas visados buvo surištas su mokymo profesija ${ }^{1}$.

Dar aštuoniolikmetis A. Vokietaitis pradeda nelengva, bet jam nepaprastai mielą mokytojo kelią: gauna vienos Kauno pradinès mokyklos mokytojo vietą. A. Vokietaitis: <...> Matyt, iš tévo jaučiau dideli patraukima mokytojauti ir todèl puoliausi su didžiausiu entuziazmu i mokytojo darbq. Tai buvo vieni kūrybiškiausiu metu. Aš taip buvau i̇sijungęs į mokytojo bei auklètojo pareigas, kad savarankiškai pasilikdavau po pamoku valandq kita su vaikais pažaisti (žaisdavom „Paskutine pora bėga“ ir kitus žaidimus) ir jaučiau, kad vaikai mane mylèjo $<\ldots>^{2}$.

$1930 \mathrm{~m}$. gavęs valstybinę stipendiją studijuoti fizinį auklëjima, A. Vokietaitis $1934 \mathrm{~m}$. sèkmingai baigè Vienos universitetą (fizinio auklëjimo ir geografijos mokslus), kartu igydamas plaukimo trenerio

\footnotetext{
${ }^{1}$ Vokietaitis, A. (2003). Raštai. Kaunas. P. 6.

2 Ten pat. P. 7 .
} 
kvalifikaciją. Fiziniu auklèjimu, ivvairių sporto šakų treniravimo metodika jis domėjosi Suomijoje (1934), SSRS (1936), Anglijoje, Švedijoje (1937).

1937-1939 m. fizini auklèjimą, psichologija, rusų filologiją studijavo Marburgo (Vokietija) universitete. Ten parengė ir apgynė filosofijos daktaro disertaciją „Esamos mokyklinės kūno kultūros sistematikos ir tautinès formos problema pirmaujančiose Europos šalyse“.

1934-1938 m. dèstė Aukštuosiuose kūno kultūros kursuose, 1931—1939 m. fizinio auklèjimo pagrindus, mankštą, plaukimą kūno kultūros mokytojų kursuose. 1939-1943 m. — VDU ir VU fizinio auklèjimo katedrų dèstytojas, nuo $1941 \mathrm{~m}$. docentas, vedèjas. $1941 \mathrm{~m}$. buvo Kūno kultūros rūmu direktorius.

A. Vokietaitis buvo ir treneris praktikas. 1934-1942 m. Lietuvos plaukimo rinktinės treneris, 1936, 1937, 1939 m. atstovavo Lietuvai tarptautiniuose fizinio auklèjimo sporto kongresuose. Daug rašè kūno kultūros, sporto klausimais.

Mokejjo vokiečiu, rusu, anglu, švedų kalbas.

Nuo 1943 m. įsitraukè ị aktyvią rezistencinę veiklą. Nuo 1949 m. gyveno JAV. Miré 1994 m. rugpjūčio 14 d. JAV. 1995 m. perlaidotas Kaune.

Už natūralius judesius, natūraliąją gimnastiką. XX a. pradžioje kuriant fizinio auklèjimo, kūno kultūros, sporto sistemą Lietuvoje, kitose Europos šalyse jau buvo suvokta šių vyksmų svarba žmogui ir valstybei. Lietuvoje reikejjo suformuoti fizinio auklejjimo, sporto samprata, išryškinti tikrają jų priedermę, net esmę.

Gražiai susidariusią situaciją Lietuvoje nupiešè kitas kūno kultūros, sporto žinovas V. Augustauskas: $<$...> Mūsu kūno kultūros sajūdis per daug greitai sukrove savo žiedus, ir plačioji visuomené nespejo dar susiorientuoti. Kūno kultūros sqmonèjimo kelias yra ilgas: juo žmonija nesiskubino eiti <...>. Auklèjimo istorijoje tai ivyko per kelis šimtus metu $<\ldots>^{3}$.

Todèl A. Vokietaičio požiūris, jo skelbtos idèjos, paremtos kitų šalių mokslo žmonių, pedagogu mintimis, pagaliau patirtimi, buvo neįkainojamos kuriant Lietuvos fizinio auklèjimo, sporto sistema, formuojant jų sampratą.

A. Vokietaitis, giliai ištyrinèjęs Austrijos fizinio auklèjimo sistemos teorinius-didaktinius pagrindus, pritare tos sistemos kūrejų K. Gaulhoferio ir M. Streicher pamatinei idèjai — natūralios gimnastikos, pagrịstos laisvais, natūraliais judesiais, taikymo pirmenybei.

Atsakydamas ị klausimą — kas yra natūralioji gimnastika - A. Vokietaitis rašè: <..> Apibūdinti natūralia gimnastika yra labai sunku, nes, apskritai sakant, tai, kas yra natūralu, sunku apbrèžti. Natūrali gimnastika yra pagrista natūraliu judesiư ${ }^{4}$. Natūralų judesị A. Vokietaitis suvokè kaip visą veiksmą, o ne judesių grupès ar judesio dali, laikydamas gerais natūralių judesių pavyzdžiais žemės arima, plaukimą, žaidimus, keliavimą, mankštinimąsi. < ..> Iš čia aiškèja, kad natüralus judesys nèra natūralios gimnastikos dalis, bet jis yra tos gimnastikos pagrindas. ${ }^{5}$

Motyvuodamas natūralios gimnastikos taikymo būtinybę, A. Vokietaitis teigè: <...> Jei kitose auklèjimo šakose yra dabar pripažistama natūralaus metodo svarba, tai ir fiziškame išsiplètojime, ir jo psicheje $<\ldots>^{6}$. Ir toliau: Gimnastika yra žaidimas savo kūno svoriu. Žmogui svarbu, kad naudodamas kuo mažiausiai jégos ta savo svori galètu kuo lengviau nugalèti. Tai yra galima tik judesi atliekant

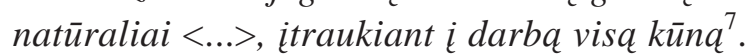

Nagrinėdamas svarbų žmogaus augimo, tobulëjimo, tvirtėjimo vyksmą — kūno lavinimą — A. Vokietaitis nesutinka su nuomone, kai kūno lavinimu laikomi visi žmogaus kūno judesiai, pasitaikantys gyvenime: kad ir grojimas kuriuo nors muzikos instrumentu. Ir čia A. Vokietaitis talkon kviečiasi K. Gaulhoferị teigdamas, kad <...> kūno lavinimas yra kiekvienas judesys, kuris biologine prasme pozityvu pajaudinima iššaukia ${ }^{8}$.

Kūną lavinantiems judesiams iškeliamos dvi būtinos sąlygos: jie turi būti biologiškai taisyklingi ir sukelti pozityvius pajaudinimus (pvz., augima).

\footnotetext{
${ }^{3}$ Augustauskas, V. (1934). Naujuoju kūno kultūros keliu. Fiziškas auklèjimas, 1, 1—2.

${ }^{4}$ Vokietaitis, A. (1931). Natūrali gimnastika ir jos pritaikymas mokyklai. Fiziškas auklëjimas, 3, 246 -253.

5 Ten pat.

6 Ten pat.

7 Ten pat.

${ }^{8}$ Vokietaitis, A. (2003). Raštai. Kaunas. P. 90.
} 
Laisvi vaikų žaidimai bus kūno lavinimas, nes jie yra biologiškai taisyklingi ir sukelia kūno ir dvasios plètojimuisi naudingus pajaudinimus.

Gimnastika - kūno kultūra plačiąja prasme. İdomi A. Vokietaičio gimnastikos, žaidimų ir plaukimo samprata, jiems skiriama vieta fiziniam lavinimui: <...> Gimnastika dažnai suprantama kaip siaura, betiksle kūno mankšta, be kurios žmogus gali apsieiti. Ne taip siaurai ta sqvoka buvo suprasta ten, iš kur ji atsirado <...>. Graikai suprato gimnastikq ne vien kaip kūno mankšta, bet kaip kūno kultūrq tikra to žodžio prasme, nors be kūno mankštos čia įejjo dar sveiko gyvenimo ipročiu ugdymas, proto lavinimas ir netikybinès apeigos $<\ldots>^{9}$.

Ieškodamas gimnastikos atsiradimo, jos požymių Lietuvoje, A. Vokietaitis aptaria keturias XX a. pradžioje Vokietijoje atsiradusiu gimnastikos mokyklu kryptis: <...> Gimnastika:

1. Išeinanti iš anatomijos — higieniška arba fiziologiška kryptis;

2. Iš šokiu;

3. Iš muzikos;

4. Iš vaidybos ${ }^{10}$.

A. Vokietaičio manymu, Lietuvoje vyravo „gimnastika iš muzikos“, vadinta „ritmine gimnastika“. Šios gimnastikos mokyklos krypties ištakos — prancūzų muzikos mokytojo Dalacroze mokykla: kūno judesių panaudojimas muzikos takto pajautimui. Jis savo metodą vadino „gimnastine ritmika“. Anot A. Vokietaičio: Gimnastika - tai planingas, pedagoginiais pagrindais tvarkomas kūno mankštos darbas ${ }^{11}$.

Žaidimai - tikroji vaikystė. Vertingas ir šiandien gilus, prasmingas A. Vokietaičio žaidimų esmès, jų svarbos vaikų, paauglių ugdymui suvokimas. Šiai problemai nagrinèti jis pasirinko įdomų analizės būdą: žaidimų ir darbo palyginimą.

Žaidimas yra psichofiziškas veikimas, kurio tikslas tas pats veiksmas, išeinas iš vidujo žaidimo reikalavimo ir to žaidejo laisvai pasirinktas.

Darbas yra veiksmas, kurio tikslas - konkretūs uždaviniai: tai yra veiksmas, kurị verčia atlikti atskiras asmuo, visuomene, aplinka, valstybe ar gyvybei palaikyti būtinas reikalas, arba, pagaliau, sažiné ir pareiga. Skirtumas tarp žaidimo ir darbo glūdi ju galutiniuose padariniuose. Žaidimo padarinys pats veiksmas. Darbo vaisius - konkretus tikslo pasiekimas. ${ }^{12}$

Ši žaidimo ir darbo skirtumą akcentuoja ir V. Augustauskas: Psichologiškai nagrinėdami darbo vyksma, pastebime jo du svarbiausius momentus — pati darbo vyksmq ir tiksla <...>. Darbe pirmauja tikslas. Šio tikslo būtinumas ir rimtumas darbo vyksma padaro įtempta ir privaloma <...>. Žaidžiame ne todèl, kad žaismu kurio nors naudingo tikslo siektume, bet žaidžiame todèl, kad patsai žaismo vyksmas yra mums malonus $<\ldots>^{13}$.

Kita vertus, žaidimo metu igyti igūdžiai, išugdytos ypatybės ir savybės yra būtinos veiksmingam darbui.

$<\ldots>$ Kiekvienam darbui atlikti reikalinga patvara, ištesèjimas ir sugebëjimas savo kūno ir dvasios jëgas valdyti, reikalingas susiorientavimas ir tam tikro miklumo laipsnis ir daugelis kitu, tiek darbui, tiek žaidimui bendru kūno ir dvasios tobulybiu.

Žmogus, kuris savo ilgos küdikystès laikotarpiu ¿̇vairiais žaidimais šiu tobulybiu neišlavintu, jei ir galètu kuri nors darbq atlikti, tai tik po ilgo pasiruošimo <...>, tokiam žmogui pats darbas yra apsunkinimas. $^{14}$

V. Augustauskas pabrèžia teigiamą žaidimų poveikị pagrindinei žmogaus veiklai: Žaismas, atstatydamas darbo griaunama dvasinę pusiausvyrq, turi labai didele itaka pačiam darbui <...>. Žaismas tuo vertingas, kad jis sukelia gerq, skaidriq nuotaika, išlygina dvasinę pusiausvyra ir tuo pačiu sutaurina darbq ir nuteikia ji geriau dirbti. Todèl ir psichologiniu, ir ekonominiu atžvilgiu žaismo reikšmé yra labai didele $\dot{e}^{15}$.

A. Vokietaitis pasiremia šveicarų mokslininko E. Klaparedo mintimis apie vaikus, neturejjusius galimybių savo gabumų išsiugdyti žaidimais: Šie nelaimingieji niekuomet nebus tikri žmonès, nes jie

\footnotetext{
9 Ten pat. P. 91.

10 Ten pat. P. 92.

11 Ten pat. P. 93.

12 Vokietaitis, A. (1934). Žaidimu reikšmė mokykloje. Fiziškas auklëjimas, 3, 230.

13 Augustauskas, V. (1937). Visuomenės poilsio ir pramogos klausimas. Fiziškas auklëjimas, 1, 4-5.

14 Vokietaitis, A. (1931). Žaidimų reikšmė mokykloje. Fiziškas auklëjimas, 3, 231.

${ }^{15}$ Augustauskas, V. (1937). Visuomenės poilsio ir pramogos klausimas. Fiziškas auklejjimas, 1, 4-5.
} 
niekuomet nebuvo vaikai. Reikalaudami iš vaiko tokio darbo, kuris nèra paremtas jo palinkimais žaisti, mes pasielgsime lygiai taip, kaip kad nukrèsdami pavasari obels žiedus: krèsdami žiedus mes netenkame vaisiu, kuriu galètume sulaukti ruden $i^{16}$.

Vienas geriausių būdų harmoningo kūno formavimui — plaukimas. A. Vokietaitis buvo geras plaukimo istorijos, didaktikos žinovas, taip pat ir praktikas - plaukimo treneris. Dèl to ir jo požiūris i plaukimą vertingas. < ..> Visi fizinio auklejimo pedagogai, taip pat fiziologai laiko plaukima vienu geriausiu būdu harmoningam žmogaus kūnui išlavinti ir jo sveikatai palaikyti. Dar ir tai i̇domu, kad plaukimas, yрас̌ ¿̇vairūs plaukimo būdai, neva nauju laiku padaras, bet viena iš seniausiai kultivuojamu mankštinimosi šaku. Net toks „modernus“ plaukimo būdas, kaip amerikiečiu kraul, pasirodo, jau 3200 m. pr. Kr. buvo plačiai naudojamas <...>. ${ }^{17}$

Apie plaukimo mokymo metodikos užuomazgas, jos evoliuciją A. Vokietaitis rašè: $<\ldots>$ Kaip jau minèjau, iki 1924 m. buvo naudojamas tik vienas, dar prieš šimta metu generolo Pfulio ìvestas plaukimo mokymo metodas. Pradedantiesiems plaukti buvo pasirinktas plaukimas krūtine. Metodas susidejjo iš dvieju pagrindiniu daliu — plaukimo pratimu sausumoje ir vandenyje. Pradžioje išmokoma plaukimo judesiu stovint (skaičiuojant iki keturiu taktu), paskui tas pats gulsčioje padettyje ant suolelio ar kèdès. Mokinys, gerai atlikęs šiuos judesius sausumoje, buvo vedamas $\dot{i}$ vandeni ir pakabinamas ant tam tikros meškerès, kur turi būti kartojami tie patys judesiai kaip sausumoje. Kai šie judesiai gerai sekasi vandenyje, mokinys ant meškerès vis daugiau atleidžiamas ir galiausiai leidžiama jam plaukti ${ }^{18}$.

Iki šiol gyvos aktyvios diskusijos apie fizinio lavinimo, auklejjimo, kūno kultūros, sporto sąvokas, ju esmę. A. Vokietaitis nesutapatino kūno ir fizinio lavinimo. Jis fizinio lavinimo esmę ir paskirtị suvokè giliau ir plačiau. Tai ne vien tik kūno lavinimas. Fizinis lavinimas yra judesiai ir veiksmai, lavinamai veikia psichofizine asmenybe <...> Fizinis lavinimas yra ne sau tikslas, o tik priemone asmenybei ugdyti, kur kūnas yra pradinis taškas, o tikslas visas žmogus. Kitais žodžiais tariant, fizinis lavinimas žmogui auklèti, bet ne vien kūnui stiprinti ir lavinti ${ }^{19}$.

Nagrinėdamas fizinio auklèjimo sąvokos atsiradimą, jos esmę A. Vokietaitis atsispiria nuo J. A. Komenskio („Kūnas - sielos namai“), St. Šalkauskio („Fizinė galybė, tik pastatyta i sąryši su dvasiniu žmogaus gyvenimu, tegali igyti aukštesnès vertès“), A. Maceinos („Kūno puoselèjimas yra prasmingas tik tada, jeigu yra dvasios persvaros ir jos laimejjimo išraiška“) išvadų ir ižvelgia fizini auklèjimą kaip visapusiško (,pilnutinio“) auklèjimo dalį. <...> Fizinio auklëjimo sqvoka $<\ldots>$ norèta ypatingai akcentuoti kūno mankštos reikšmę žmogaus auklëjimui $<\ldots>^{20}$.

A. Vokietaitis laiko klaida, kai auklèjimas suvokiamas tik kaip dvasinių galių plètojimas. $<\ldots>$ Čia buvo didele klaida. Buvo pamiršta, kad žmogus be dvasios turi dar ir kūnq ir jie abu sykiu sudaro viena neišskiriamq vieneta - žmogu.

Koks glaudus ryšys yra tarp kūno ir dvasios ir kaip jie abipusiškai veikia vienas kita, nurodo mums ir psichologijos mokslai. Vadinasi, ugdant kūnq plètojamos ir dvasinès galios (pvz., pasiryžimas, drqsa, valia). Todèl dabar modernioji pedagogika, ¿̇vertindama ta abipusí, neišskiriama dvasios ir kūno veikima, kalba apie pilnutinĭ žmogaus auklèjima, bet ne apie jo intelekto ar kūno auklèjima atskirai. Išeinant iš to atrodytu, kad sqvoka „fizinis auklëjimas“ bütu netikslu vartoti, nes kūno auklèjimo kaipo tokio negali būti. Šis priekaištas būtu visai pateisinamas, jei mes auklëjime būtume jau taip toli paženge, kad kūno ugdyma suprastume kaip neišskiriama, organinę žmogaus auklejjimo dalị. Deja, dabartiniu metu turime dar gerokai pakovoti, kad kūno mankšta užimtu auklejjime sau prideramq vieta ir nebūtu laikoma pašaliniu dalyku. Dèl šiu priežasčiu ir paliekame dar ta sqvoka „fizinis auklèjimas“, norèdami tuo pabrëžti, kad per kūnq mes siekiame bendrojo auklëjimo. ${ }^{21}$

Pateiktame A. Vokietaičio fizinio auklèjimo apibrèžime nesunku pastebėti panašumą su Vakaru Europos šios sąvokos samprata. A. Vokietaitis teigia: Fizinis auklëjimas yra integraliné pilnutinio auklejjimo dalis. Tai yra tam tikras auklejjimo aspektas — auklèjimas „per kūnq“, t. y. per psichofizinius žmogaus motorikos veiksmus ${ }^{22}$.

\footnotetext{
${ }^{16}$ Vokietaitis, A. (1931). Žaidimų reikšmė mokykloje. Fiziškas auklejjimas, 3, 234.

${ }^{17}$ Vokietaitis, A. (1932). Plaukimas. Fiziškas auklèjimas, 2, 162-176.

18 Ten pat.

${ }^{19}$ Vokietaitis, A. (1948). Fizinio auklèjimo krypties keitimo klausimu. Žiburiai, 12 (122).

${ }^{20}$ Vokietaitis, A. (1932). Dėl kūno mankštos sąvokų. Fiziškas auklèjimas, 1, 22-23.

21 Ten pat.

${ }^{22}$ Vokietaitis, A. (1948). Fizinio auklèjimo krypties keitimo klausimu. Žiburiai, 12 (122).
} 
Anot austrų pedagogo K. Gaulhoferio: Fizinis auklëjimas yra tai bendras auklëjimas, kuris išeina iš kūno. Tad fiziniu auklèjimu vadintume <...> visas priemones ir veiksmus, kurie per kūnq veda $\dot{\imath}$ kultūrqq.

Kūno kultūra - pirmiausia tai kultūra. A. Vokietaitis dar ketvirto XX a. dešimtmečio pradžioje apie kūno kultūros sąvoką, esmę ir priedermę rašè: Tai nauja squvoka $<\ldots>$, kuri atsirado, kai buvo suprasta ta didelè kūno mankštos vertè žmonijos kultūrai $<\ldots>^{24}$.

Kūno kultūros esmei atskleisti A. Vokietaitis pasitelkia Austrijos fizinio auklèjimo sistemos kūrèją K. Gaulhoferị ir reziumuoja: Pirmiausia kūno kultūros squvoka galima būtu suprasti kaip grynai kūno lavinima, vadinasi, kūno galiu ugdyma, bet šis pilnas kūno jègos, vikrumo ir atsparumo pasiekimas yra ir be jokios kultūros i̇manomas; žmogus gali būti tvirtas ir sveikas ir vis tik nekultūringas. Gal tai yra tuomet kūno ugdymas. Žinoma, kūno ugdymas yra labai svarbus gyvenimo faktorius, bet jis gali išsigimti z gryna kūno kulta, kuris gyvenimui yra visai svetimas. Apie kūno kultūrq tikraja to žodžio prasme galime tik tada kalbèti, kai kūno lavinimas bei ugdymas, prisilaikydamas moralès principu, aukštesniam dvasiniam tikslui tarnaus <...>. Kūno kultūra yra tai kūno lavinimas bei ugdymas, kuris biologiniu ir moralès istatymu vedamas dvasinio tikslo siekia ${ }^{25}$.

A. Vokietaitis ypač akcentuoja kūno kultūros ir bendrosios kultūros sąsają. <.. > Jei pasirenkame ta sqvokq, tai turime suprasti, kad pirmiausia čia kalbama apie kultūrqq. O juk kultūra yra aukščiausias tautos siekimas. Žuvus kultūrai, žūsta ir pati tauta. Kultūroje išskiriama dvasios ir kūno kultūra. Dvasios kultūra galima pavadinti ta keliq, kuris, išeinant iš dvasiniu galiu plètojimo (pvz., mokslo, meno, religijos), veda ì tautos ar pagaliau žmonijos kultūrą. Tas pats ir su kūno kultūra. Tai bütu tas kelias, kuris, išeinat iš kūno, vestu $\dot{k}$ bendrq kultūrq. Kitaip tariant, kūno kultūra yra visi tie faktoriai (pvz., kūno mankšta, laisvi liaudies žaidimai, sveiko gyvenimo ìpročiai ir t. t.), kurie per kūnq siekia bendros kultūros. Tuos paskirus faktorius - kūno mankšta (plačiaja prasme), pedagoginę mankšta, higiena ir t. t. dar negalime vadinti kūno kultūra; paimti visi kartu iggaus kūno kultūros varda $<\ldots>$. Kūno kultūra apima viska, kas, išeinant iš kūno, siekia kultūros. ${ }^{26}$

Sportas - tam tikra kūno lavinimo forma. XX a. ketvirtame dešimtmetyje A. Vokietaičio pateiktas sporto suvokimas nemaža dalimi siejasi ir su mūsų dienomis. <...> Dabartiniu metu „,sportuojama" visose gyvenimo srityse. Ar tai žaidžiama futbolas, bėgama, šokama ar metama, plaukoma, važiuojama automobiliu, skraidoma lèktuvu, žaidžiamas biliardas ar šachmatai - visa tai vadinama sportu. <...> Buvo ìvestas naujas pavadinimas „proto sportas“ (šachmatu uždaviniai, rebusai). Neretai skaitome apie foto sporta. Modernusis šokis priskiriamas taip pat sportui ir net isteigti šokiu sporto klubai. Čia nekalbèsime apie grynai amerikoniška valgymo, gèrimo, badavimo, nemigos ir t. t. sporta. Ši pavyzdžiu užteks parodyti, kaip dabartiniu metu suprantamas sportas. Jis, kaip matome, apima ¿vairiausias gyvenimo sritis, kuriu daugelis nieko bendro su kūno lavinimu neturi $<\ldots . .>^{27}$.

Peržvelgdamas sporto, kaip socialinio reiškinio, ontogenezę, A. Vokietaitis pabrěžè, kad pirmykštè sporto reikšmẻ buvo prasiblaškymas, pramoga, laiko praleidimas, žaidimai, todèl pirmosios sporto šakos buvo žūklavimas ir medžioklè. Tik vèliau šis terminas imtas taikyti bėgimo, šuoliavimo, mètymų varžyboms. Sporto sąvokai apėmus ir kitas veiklos sritis, norint atskirti jas nuo kūno lavinimo, netgi buvo įvestas terminas „kūno sportas“.

Norėdamas parodyti ịvairių Europos šalių pedagogų, kūno kultūros žinovų požiūrị i sportą, jo samprata, A. Vokietaitis ir čia pasitelkia žinomus autoritetus.

K. Gaulhoferis teigia: Sportas gali būti charakterizuojamas kaip aukščiausio rezultato siekimas nors ir siauriausioje srityje $<\ldots{ }^{28}$.

Šveicarų gydytojas Hugas sako: Sportas savo žaidimuose siekia aukščiausio rekordo. Jo tikslas išviršinis rezultatas, bet ne visapusiškas žmogaus lavinimas ${ }^{29}$.

O. Beckmanas, reikšmingo XX a. pradžioje pasirodžiusio žodyno autorius: Sportiškas kūno mankštos pavidalas yra tai žaidimas su rungtyniavimo pradu, bendruomeniškai organizuotas ir pagal nustatytas

\footnotetext{
${ }^{23}$ Vokietaitis, A. (1932). Dèl kūno mankštos sąvokų. Fiziškas auklejjimas, 1, 22-33.

24 Ten pat.

25 Ten pat.

${ }^{26}$ Vokietaitis, A. (1934). Dèl kūno mankštos sąvoku. Fiziškas auklèjimas, 1, 22-33.

27 Ten pat.

${ }^{28}$ Vokietaitis, A. (2003). Raštai. Kaunas. P. 94.

${ }^{29}$ Ten pat. P. $94-95$
} 
taisykles atliekamas žmogaus veiksmas <...>. Kūno lavinimas ir sportas yra priimta laikyti tolygiai, bet tas jokiu būdu neleistina. Vadinasi, pats kūno lavinimas tai nèra dar sportas, bet sportas yra tam tikra kūno lavinimo forma ${ }^{30}$.

Pasiremdamas pateiktomis sporto sampratomis, A. Vokietaitis priëjo prie išvadu̧, kad sportas tai dar nẻra kūno lavinimas, nẻra kuri nors pratimų grupė, kad sportišką pobūdị gali turèti ịvairios kūno lavinimo šakos, kad sportas yra šių dienų pasireiškimas, tai yra sociologinè sąvoka, kuri kiekvienoje šalyje gali būti įvairiai suprantama.

A. Vokietaičio nuomone, vyravusios sporto sąvokos turejjo esminę spragą: jose nematyti, $<\ldots>$ kad sportu siekiame kultūros ar bendrojo auklëjimo <...> Mums reikètu dar gerokai pagalvoti, ar tikslu duoti sportui tokiq plačiq prasmę <...> Atrodo bütu tiksliau vietoj dabar pas mus vartojamo termino sportuoti kai kuriais atvejais vartoti daug aiškesnę tik gal mums ne taip iprasta sqvoka - mankštintis ${ }^{31}$.

Fizinio auklẻjimo teorijos ižvalgos, tyrimų išvados - i praktiką. A. Vokietaitis buvo ne tik fizinio auklèjimo, kūno kultūros žinovas-teoretikas. Jis mokslo, patyrimo žinias aktyviai taikè praktikoje. Visų pirma, kuriant ir igyvendinant mokyklinę fizinio auklejjimo sistemą.

Ketvirto XX a. dešimtmečio pradžioje A. Vokietaitis, susipažinęs su Vakarų Europos šalių mokyklu kūno kultūra, fiziniu auklèjimu, pateikè pakitusi požiūrị i kūno kultūra, kaip mokyklose dèstomą dalyką: <...> Ligi šiol gimnastika mokykloje èjo visai atskiru dalyku ir jos desstyme nebuvo atsižvelgiama $\dot{k}$ vaiko sielq ir jo kūno išsiplètojima. Küno kultūros mokytojai, pasiemę pagrindu kuriq nors gimnastikos sistema $<\ldots>$, stengdavosi vaikus išmokyti kuo daugiau pratimu, neatsižvelgdami i ju auklejjamaja reikšmę <...> Dabartiniu fizinio auklëjimo pedagogu supratimu, vaiko fizinis auklëjimas turi eiti kartu su kitais mokykloje dèstomais dalykais ir kartu sudaryti ištisini auklejjimq, nes fizinis auklejjimas yra tik ištisinio auklèjimo dalis $<\ldots>^{32}$.

<...> Tik ìsteigus Kaune Kūno kultūros rūmus (1932 m.), fizinis auklèjimas igavo nauja kryptį. Dr. A. Vokietaičiui vadovaujant, buvo sudaryta pagal dr. Gaulhofer ir dr. Streicker pedagogines idejas atitinkama mūsu krašto salygoms mokykline fizinio auklejjimo sistema $<\ldots>^{33}$.

Igyvendindami natūraliają gimnastiką mokykloje, jos šalininkai pateikè savo motyvus, kartu atskleidè natūraliosios gimnastikos esmę: senosios gimnastikos tikslas daugiausia buvo išmokyti vaikus kiek galint daugiau judesių ir juos atlikti taip, kaip reikalauja mokytojas, t. y. tam tikru būdu, tam tikra forma. Gražiai nusake ir konkrečius natūraliosios gimnastikos mokykloje tikslus, uždavinius.

O dabar visas demesys yra kreipiamas i judesio tiksla. Jei mes duodame vaikui atlikti koki nors judesi, turime pirmiausia žinoti, kaip jis veikia vaiko kūna, kuo jis vaikui yra naudingas ir kaip pagaliau vaikas pasieks tiksla <...>. Mes neklausiam „kq gali mūsu mokinès?“, bet klausiam „ar turi mūsu mokinès laisva, gražiq laikysenq, ar teisingai jos kvépuoja, ar gali ju kūne esantị saikq kasdieniniams judesiams ir darbui teisingai pavartoti, ar žino jos, kaip galima savo sveikatq tobulinti ir ar moka jos tas žinias pritaikyti “334.

Dar vienas svarbus darbas, prie kurio prisidejjo A. Vokietaitis - kūno kultūros programos kaimo jaunimui parengimas (kartu su K. Dineika, M. Baronaite, V. Petroniu ir kt.). <..> Norint paversti kūno kultūrq auklèjimosi bei kultūrinimosi priemone, tenka pagalvoti apie konkrečius metodus, kuriais užsibrëžto tikslo sieksime. Jau daugelis Europos valstybiu, gerai suprasdamos ir ìvertindamos kūno kultūros reikšmę visam tautos ir valstybès gyvenimui ir jo kultūriniam kilimui, bande i̇vairias kūno kultūros pasireiškimo formas padaryti visiems valstybès piliečiams privalomas, visuotines $<\ldots>^{35}$.

Programa apėmè specifinę mankšta, higienos klausimus, varžymosi pobūdžio pramogas, iškylas ir keliavimą. Apie programos rengima, jos igyvendinimą A. Vokietaitis rašė: <...> Žinoma, šitas darbas nelengvas, nes tai visai naujas bandymas ne tiktai pas mus Lietuvoje, bet ir Europoje. Todèl negalime reikalauti, kad programa būtu visiškai tobula. Ji tobulès tik laikui bėgant $<\ldots>^{36}$.

A. Vokietaičio darbai išlieka reikšmingi kūno kultūros, sporto mokslui, gyvenimo praktikai ir dabar.

\footnotetext{
30 Beckmann Sport Lexikon. (1933). Leipzig, Wien. P. 2099.

${ }^{31}$ Vokietaitis, A. (1934). Dèl kūno mankštos sąvokų. Fiziškas auklèjimas, 1, 22-32.

${ }^{32}$ Vokietaitis, A. (1931). Fizinio auklèjimo mokytojų paruošimas Austrijoje. Fiziškas auklèjimas, 1, 45-51.

${ }^{33}$ Narbutas, J. (1978). Sportas Nepriklausomoje Lietuvoje. D.1. Čikaga. P. 71.

${ }^{34}$ Vokietaitis, A. (1931). Natūralinė gimnastika ir jos pritaikymas mokykloje. Fiziškas auklëjimas, 3, 251.

${ }^{35}$ Vokietaitis, A. (1936). Kūno kultūros programa organizuotam kaimo jaunimui. Fiziškas auklejjimas, 3, $95-101$.

36 Ten pat.
} 
For the 100 years anniversary

\title{
A. VOKIETAITIS - ONE OF THE CREATORS OF THE SYSTEM OF LITHUANIAN PHYSICAL EDUCATION AND SPORT: THEORETICAL INSIGHT AND PRACTICE
}

\author{
Stanislovas Stonkus \\ Lithuanian Academy of Physical Education, Kaunas, Lithuania
}

\begin{abstract}
With the increasing attention to physical education and sport more and more people try to define their attitudes towards physical education, sport, their moral and educational values and the application factors, and they want to find their place in those processes.

The article deals with A. Vokietaitis' fundamental theoretical statements, presented in the 1930s, their application in practice, and their influence in the development of the system of the Lithuanian physical education and sport. Those statements have not lost their theoretical and practical significance even now.

A. Vokietaitis considered natural gymnastics to be an important factor in the development of the human body. Physical education should emphasize gymnastics, sports games and swimming.

Among the most important concepts A. Vokietaitis distinguished physical training, physical education, physical development and sport. He emphasized the links between physical education and culture. Sport was perceived as a form of human body development without seeking for the overall human culture.

A. Vokietaitis implemented his theoretical assumptions into practice creating the system of school physical education and physical education for the young people in the country.
\end{abstract}

Keywords: natural movement, natural gymnastics, body development, physical education, sport.

Gauta 2009 m. sausio 25 d.

Received on January 25, 2009

Priimta $2009 \mathrm{~m}$. kovo $5 \mathrm{~d}$.

Accepted on March 5, 2009

Stanislovas Stonkus

Lietuvos kūno kultūros akademija

(Lithuanian Academy of Physical Education)

Sporto g. 6, LT-44221 Kaunas

Lietuva (Lithuania)

Tel +370 37302636

E-mail zurnalas@lkka.lt 